\title{
Flow cytofluorometric analysis of granulosa cell proliferation in rats
}

\author{
A. N. Hirshfield, G. L. Flickinger* and Z. Ben-Rafael*† \\ Department of Anatomy, University of Maryland School of Medicine, Baltimore, Maryland 21201, \\ U.S.A. and ${ }^{*}$ Department of Obstetrics and Gynecology, Hospital of the University of Pennsylvania, \\ Philadelphia, Pennsylvania 19104, U.S.A.
}

\begin{abstract}
Summary. Immature rats were given PMSG followed by an ovulatory dose of hCG. Mature cyclic rats were given an ovulatory dose of hCG on the day of dioestrus, $24 \mathrm{~h}$ before the endogenous LH surge was expected to occur. Granulosa cells from individual follicles were subjected to flow cytometry at various times after hormone administration. Administration of PMSG to immature rats caused a marked, transient increase in 'cycling' granulosa cells (cells in S, G2, or M phases of the cell cycle). Administration of hCG to adult cyclic rats caused a slight, but significant, increase in 'cycling' granulosa cells. The results could be taken to indicate that hCG-induced luteinization is not, in fact, accompanied by cessation of cellular proliferation. However, the data lend themselves to alternative explanations. The observed phase shifts may be due to the lengthening of the duration of $S$ and $G 2$ phases, indicating an actual decrease in the rate of cell proliferation. Flow cytometry was found to be a rapid, inexpensive tool for the study of follicular growth in the rat, but, due to variation between follicles and the need for a minimal sample size of 2000 cells, its application is limited to large follicles.
\end{abstract}

Keywords: flow cytometry; follicle; granulosa cell; rat; cell proliferation

\section{Introduction}

Many problems remain unresolved concerning the control and temporal dynamics of granulosa cell proliferation in vivo. Most investigators have relied upon inexact morphometric procedures (measuring follicular size) or laborious and time-consuming autoradiographic methods $\left(\left[{ }^{3} \mathrm{H}\right]\right.$ thymidine incorporation) to study follicular growth. However, a few recent studies of human tissues (Westergaard et al., 1982; Westergaard, 1985; Ben-Rafael et al., 1987) suggest that flow cytometry may provide a quick and easy approach to the investigation of cell proliferation in the ovary.

Flow cytometry has proved useful for the study of cell proliferation in a variety of tissues (Van Dilla et al., 1985). In this procedure, the DNA content of individual, isolated cells can be measured rapidly, resulting in a frequency distribution which reflects the proportion of cells in each stage of the replicative cell cycle.

Using this methodology, Westergaard (1985) found a 'high correlation' between the morphological appearance of aspirated human oocytes and the proportion of granulosa cells in $\mathbf{S}$ phase. Ben-Rafael et al. (1987) found that the proportion of 'cycling' granulosa cells (in S, G2 or M phase) in human follicles was inversely correlated with follicular-fluid progesterone concentration, suggesting that mitotic activity is decreased when granulosa cells become luteinized.

†Present address: Department of Obstetrics and Gynecology, The C. Sheba Medical Center and Sackler School of Medicine, Tel-Hashomer 52621, Israel. 
The experiments reported here were undertaken to evaluate flow cytometric methods for extensive use in studies of granulosa cell proliferation during follicular development in the rat. We particularly wished to determine whether flow cytometry could be used to discriminate between cells from healthy versus atretic follicles in the rat, as it has been reported to do in the human (Westergaard et al., 1982). A further aim was to test the hypothesis that luteinization causes an obligatory cessation of granulosa cell proliferation (Rao et al., 1978).

\section{Materials and Methods}

Animals. Sprague-Dawley-derived rats were obtained from Dominion Laboratories (Dublin, VA). They were housed in temperature- and light-controlled rooms with a lighting schedule of $12 \mathrm{~h}$ darkness:12 h light (lights on at 07:00 h). Three different experimental manipulations were performed. After these manipulations, one ovary from each animal was saved for histological examination and the other ovary was dissected to obtain follicles for flow cytometry analysis.

Experiment 1: stimulation of granulosa cell proliferation with PMSG. Rats were given a single injection of 20 i.u. PMSG (Sigma Chemical Co, St Louis, MO) at $10: 00 \mathrm{~h}$ on Day 26 of life. Control rats were injected with 0.2 ml phosphate-buffered saline (PBS). The hormone-treated $(\mathrm{N}=5)$ and control $(\mathrm{N}=5)$ rats were killed with an overdose of ether at 10:00 h on Day 27 of life.

Experiment 2: alterations in granulosa cell proliferation following an ovulatory dose of hCG. Rats were given a single injection of 20 i.u. PMSG at $07: 30 \mathrm{~h}$ on Day 26 of life. After $48 \mathrm{~h}$, half of the animals were injected with $10 \mathrm{i} . \mathrm{u}$. hCG (Sigma Chemical Co.); the remaining control rats received $0.2 \mathrm{ml}$ PBS. Control and hormone-treated rats were killed at $12: 30 \mathrm{~h}$ ( $5 \mathrm{~h}$ after injection; 5 rats per group) or $17: 30 \mathrm{~h}$ ( $10 \mathrm{~h}$ after injection; 5 rats per group).

Experiment 3: effect of $h C G$ on large follicles at dioestrus. Young adult rats $(180 \mathrm{~g})$ displaying at least 2 unambiguous 4-day oestrous cycles were injected with $10 \mathrm{i}$.u. hCG $(\mathrm{N}=6)$ or saline $(\mathrm{N}=3)$ at $07: 30 \mathrm{~h}$ on the day of dioestrus. The rats were killed at $12: 30 \mathrm{~h}$ ( $5 \mathrm{~h}$ after injection).

Isolation of follicles and granulosa cells. Ovaries were removed, cleaned of surrounding fat, and placed in iced PBS. The 4 largest follicles from each ovary were dissected free from the ovarian stroma using a pair of watchmakers' forceps and a dissecting microscope. Aliquants of PBS $(200 \mu 1)$ were placed in the depressions of a 'milk count' slide (VWR Scientific, Baltimore, MD) and one follicle was placed in each drop of liquid. Each follicle was visually inspected under high power of the dissecting microscope ( $\times 40$ magnification) and measured across the largest diameter, using a calibrated ocular reticule in the eyepiece of the microscope. The follicle was then torn open with a pair of clean forceps, the granulosa cells were scraped off the thecal wall into the drop of PBS and the thecal shell was discarded. The condition of the cumulus oophorus surrounding the extruded oocyte was noted because the oocytecumulus complex undergoes characteristic changes during atresia. In histological sections, the cumulus layers of atretic follicles are noticeably thinner than those of healthy follicles; cumulus cells form a compact multilayered case around oocytes of healthy follicles while portions of the oocyte in atretic follicles may be entirely devoid of covering cumulus cells.

The granulosa cells in each sample were gently dispersed into the medium by aspiration through a 27 -gauge needle. A 10- $\mu \mathrm{l}$ sample of the cell suspension was spotted onto a microscope slide and allowed to air dry. The remaining $190 \mu \mathrm{l}$ of the cell suspension were transferred to a $2-\mathrm{ml}$ vial containing $200 \mu \mathrm{l}$ carbowax fixative ( $2 \%$ carbowax 1450 in $95 \%$ ethanol; Cytospin Collection Fluid: Shandon Southern Instruments, Inc., Sewickley, PA). These samples were stored at room temperature in the carbowax fixative until used for flow cytometry.

Flow cytometry. Fixed cells were pelleted and resuspended by vortexing in $2 \mathrm{ml} 0.1 \mathrm{M}$-Tris- $\mathrm{HCl}$ buffer, $\mathrm{pH} 7 \cdot 4$, containing $5 \mu \mathrm{l} \mathrm{4}$, 6-diamidino-2-phenylindole (Aldrich Chemical Co., Milwaukee, WI), $0 \cdot 1 \mathrm{M}-\mathrm{NaCl}$ and $0.04 \mathrm{M}-$ $\mathrm{MgCl}_{2} \cdot \mathrm{H}_{2} \mathrm{O}$. Before flow analysis, the cell suspensions were passed through a $53-\mu \mathrm{m}$ nylon mesh filter to remove aggregated cells. Flow cytofluorometric measurements were made with an ICP-22Z impulse cytophotometer (Ortho Instruments, Westwood, MA) equipped with a high pressure 100-W mercury arc lamp (Osram, type HBO $100 \mathrm{~W} / 2$ : Leitz, Rockleigh, NJ), a Zeiss $\times 100$ neofluor objective, a UG-1 filter for peak transmittance at $360 \mathrm{~nm}$, and a FITC special barrier ( $450-490 \mathrm{~nm}$ bandpass) filter for emission. The instrument has a built-in pulse height analyser and integrator (Ortho Instruments 2103 distribution analyser) so that the total population under a peak in the DNA histogram is automatically calculated (Ben-Rafael et al., 1987). Histograms were plotted with a Hewlett Packard $7010 \mathrm{~B} X-Y$ recorder (King of Prussia, PA). DNA histograms were corrected for peak deviations and CV (coefficient of variation) with a program written by the late Dr Walter Tsou (University of Pennsylvania-Presbyterian Medical Center) for an Apple computer (Tsou et al., 1984).

Histology. Ovaries were cleaned, fixed in Kahle's fixative ( 5 parts $40 \%$ formalin, 15 parts $95 \%$ alcohol, I part glacial acetic acid, 30 parts distilled water; Gurr, 1956), dehydrated and embedded in Paraplast using routine histological procedures. They were serially sectioned at $8 \mu \mathrm{m}$ and stained with Weigert's haematoxylin followed by a picric acid and methyl blue counterstain (Luna, 1968). Cytological smears of granulosa cells were fixed with Spray-Cyte (Clay Adams, Parsippany, NJ), then stained with Lee's methylene blue-basic fuchsin stain (Bennett et al., 1976). 
Data analysis. Data from samples with fewer than 2000 cells were excluded from statistical analyses because the flow cytometer cannot accurately measure such small samples (Westergaard et al., 1982). The remaining follicles were analysed by taking the arc sine square root of the phase fractions (to make the percentile data more nearly normal and homoscedastic; Bartlett, 1947) and testing for statistical differences by one-way ANOVA followed by Newman-Keul's test for significance $(P=0.05$; Winer, 1971).

\section{Results}

\section{Observations during dissection of follicles}

Follicles of rats killed $10 \mathrm{~h}$ after exposure to hCG were exceedingly friable and were easily ruptured. The granulosa cells clung tenaciously to each other and to the follicular wall; as a result, most of the samples had too few cells for flow cytometry. In consequence, so few data points were obtained that the entire group was excluded from further analysis. Large follicles of immature rats given PMSG, and large follicles of dioestrous rats, were easily dissected free of the surrounding ovarian tissue. When ruptured, they exuded a stream of granulosa cells into the collecting medium.

During dissection and cleaning of follicles, an effort was made to distinguish healthy from atretic follicles. In the mouse, isolated atretic follicles appear darker than healthy follicles when viewed under transillumination (A. G. S. Byskov, personal communication). We were unable to confirm this observation in the rat. Some follicles appeared darker than others, but the frequency of dark follicles was not correlated with the frequency of atretic follicles in the histological preparation of the contralateral ovary. Other possible indicators of atresia in dissected follicles included clear patches in the follicular wall and extruded oocytes lacking large cumuli. These characteristics were noted for individual follicles.

\section{Flow cytometry}

Most of the DNA distributions had clearly defined G0/G1 peaks and G2 + M peaks, with G1/G2 ratios of approximately 2 . The coefficient of variation of the G0/G1 peak ranged from 4.6 to 18 and averaged $8 \cdot 58$ overall. The number of cells per sample varied with the hormonal treatments, but was not closely correlated with the diameter of the unfixed follicle (Fig. 1). A few of the DNA histograms deviated from the usual pattern. Most of these unusual histograms were derived from samples containing $<5000$ cells. Unusual features included: a shoulder on the left-hand side of the G0/Gl peak; a bimodal G1 peak, and a very small peak at approximately $\times 3 \mathrm{G} 1$. Two histograms consisted of a single, wide peak. All samples that deviated greatly from the usual pattern upon visual inspection were eliminated from further statistical analysis.

Cell cycle phase fraction distributions varied considerably from follicle to follicle within a single animal (Fig. 2). For example, in one cyclic rat killed at $12: 30 \mathrm{~h}$ on the day of dioestrus, the $\mathrm{S}$ phase fraction ranged from $3.8 \%$ in one follicle to $13 \cdot 3 \%$ in another. However, there was no significant difference in between-rat variance in phase fractions within the same treatment group.

Hormone treatment significantly altered the phase fraction distribution of granulosa cells from antral follicles (Fig. 3). At 1 day after injection of PMSG, the percentage of 'cycling' cells $(\mathrm{S}+\mathrm{G} 2+\mathrm{M})$ in immature rats rose from a mean of $27 \%$ per follicle (controls) to $40.4 \%$ per follicle. This effect of PMSG was short-lived; by 2 days after injection the proportion of 'cycling' cells had fallen to $29 \cdot 7 \%$ (still significantly higher than control levels). The proportion of 'cycling' cells $(30 \cdot 3 \%)$ in rats given hCG $48 \mathrm{~h}$ after PMSG treatment was not significantly different from that in rats given $\mathrm{PMSG}$ alone.

Administration of hCG to dioestrous adult rats led to a significant increase in the proportion of cells in the $\mathrm{S}+\mathrm{G} 2+\mathrm{M}$ phases (30.8\%) compared with dioestrous controls (26.4\%; Fig. 3).

\section{Discussion}

Using flow cytometry, we were able to demonstrate changes in granulosa cell proliferation after administration of gonadotrophins. PMSG administered to immature rats increased the proportion 


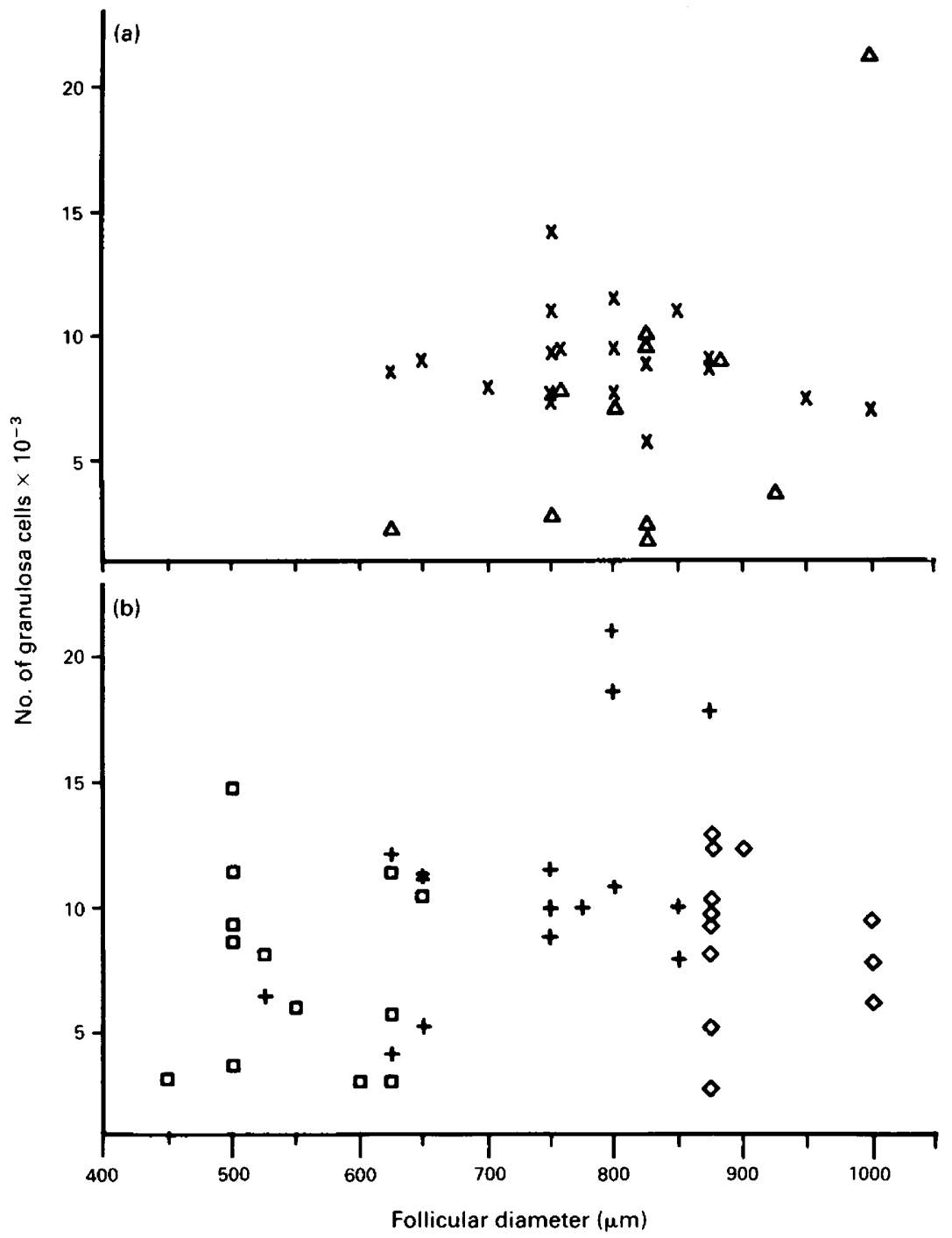

Fig. 1. Relationship between the diameter of a follicle and the number of granulosa cells harvested from it: (a) adult rats $(\Delta=$ untreated adult dioestrous; $x=$ adult dioestrous given hCG $24 \mathrm{~h}$ previously) and (b) immature rats ( $\square=$ saline-injected, control immature; $+=$ PMSG $24 \mathrm{~h}$ before being killed; $\diamond=$ PMSG, followed by hCG $48 \mathrm{~h}$ later, killed $5 \mathrm{~h}$ after hCG).

of 'cycling' cells ( $S+G 2+M$ phase). $H C G$ administered to adult rats also increased the proportion of cells in $\mathbf{S}+\mathbf{G} 2+\mathbf{M}$ phases compared with untreated dioestrous controls.

Our cytofluorometric results corroborate reports using other techniques which have shown that FSH/PMSG stimulates proliferation of granulosa cells (Peluso \& Steger, 1978; Eshkol \& Pariente, 1984; Hirshfield, 1985; Roy \& Greenwald, 1986). There was a marked increase in 'cycling' cells within $24 \mathrm{~h}$ of PMSG administration to immature rats. The effect of PMSG treatment was transient; within $48 \mathrm{~h}$ the proportion of 'cycling' cells had returned nearly to control values.

Low S-phase fractions were seen in nearly all follicles. This observation was unexpected. Granulosa cells proliferate rapidly, even when not stimulated by exogenous PMSG (Pedersen, 


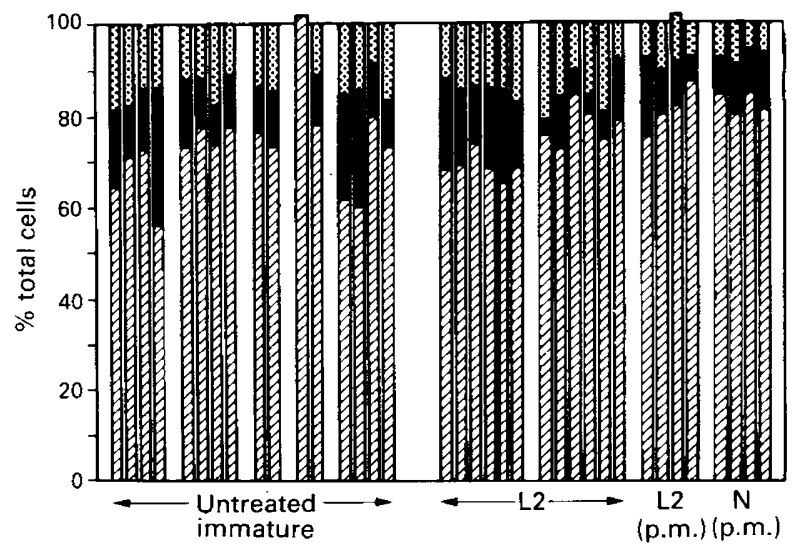

Fig. 2. Phase fractions of granulosa cells from individual follicles of untreated rats. Follicles from a single rat are grouped together. Note that because of correction of peak deviation, phase fractions of 2 follicles add up to more than $100 \%$. The hatched portion of each bar represents the G0/G1 phase fraction. The black portion of each bar represents the $S$ phase fraction. The stippled portion of each bar represents $\mathrm{G} 2+\mathbf{M}$ phase. Untreated immature = saline-injected control immature rats killed at 27 days of age; $\mathrm{L} 2$ = adult rats killed at $12: 30 \mathrm{~h}$ on dioestrus; $\mathrm{L} 2$ (p.m.) = adult rats killed at 17:30 h on dioestrus; $\mathrm{N}$ (p.m.) = adult rats killed at 17:30 h on the day of pro-oestrus.

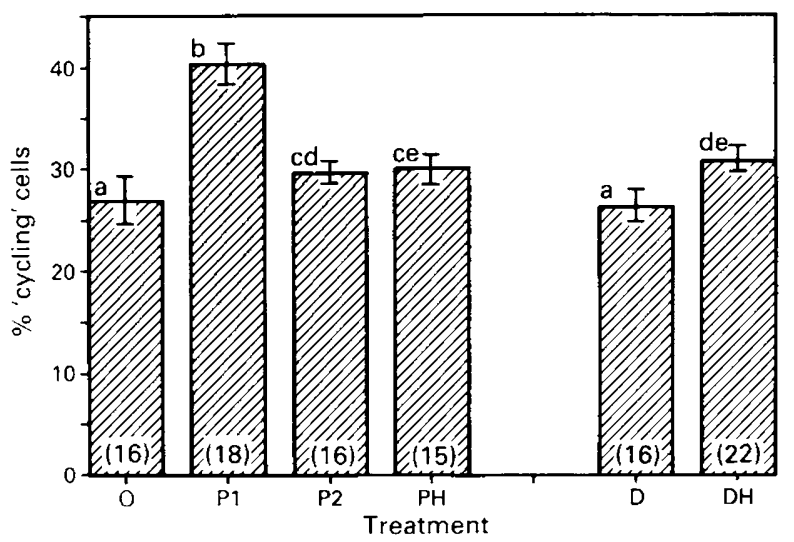

Fig. 3. Effect of hormone treatment on the proportion of cells in the G0/G1 phase. Values are mean \pm s.e.m. for all follicles in the treatment group. Values which do not share the same letter are significantly different from each other $(P<0.05)$. $O$, Control, immature rats; P1, immature rats + PMSG for $24 \mathrm{~h}$; P2, immature rats + PMSG for $48 \mathrm{~h}$; PH, immature rats + PMSG + hCG; $\mathrm{D}$, adult dioestrous rats; $\mathrm{DH}$, adult dioestrous rats $+\mathrm{hCG}$.

1969, 1970; Hage et al., 1978; Hirshfield, 1985, 1986). Other rapidly growing tissues have a high proportion of 'cycling' cells ( $71 \%$ in jejunum of mouse, $54.3 \%$ in colon: Cheng \& Bjerknes, 1983), while slowly growing tissues have few 'cycling' cells (14.5\% in hamster tongue: Rubin et al., 1983). It was therefore surprising to find that, even after PMSG stimulation, an average of only $40.4 \%$ of granulosa cells were in $\mathbf{S}$ or $\mathbf{G} 2+\mathbf{M}$ phases. The highest proportion of 'cycling' cells seen in any individual follicle studied was $59.4 \%$; few follicles exceeded $45 \%$. These results may reflect the fact that we obtained granulosa cells from large, preovulatory follicles whose proliferative potential is 
nearly exhausted (Hirshfield \& Schmidt, 1987), rather than medium-sized follicles which are growing rapidly.

Studies using incorporation of $\left[{ }^{3} \mathrm{H}\right]$ thymidine indicate that most luteal cells do not divide (Peters \& Levy, 1966; Hirshfield, 1984; Tamura \& Greenwald, 1987). In addition, flow cytometry of preovulatory human granulosa cells indicate an inverse correlation between the follicular fluid progesterone concentration and the fraction of 'cycling' cells (Ben-Rafael et al., 1987), suggesting that granulosa cells cease proliferation as they begin to luteinize. On the basis of these observations, we proposed that hCG, administered 1 day before the LH surge, would further suppress cell proliferation by triggering premature luteinization. As expected, follicles of rats killed on the day of pro-oestrus contained very few 'cycling' cells (16.9\%; Fig. 2). However, we were surprised to find that, $5 \mathrm{~h}$ after hCG treatment, follicles of dioestrous rats had more $\mathrm{S}+\mathrm{G} 2+\mathrm{M}$ cells than did untreated controls.

There are at least three possible mechanisms that could explain an increase in the proportion of 'cycling' cells. Two of these mechanisms involve a true increase in cell proliferation in the tissue: (1) the growth fraction (proportion of cycling cells) in the total population may have increased or (2) the length of the G1 phase may have decreased as a result of hormonal stimulation. If the observed phase shifts occurred by one of these two mechanisms, then our hypothesis that $\mathrm{LH} / \mathrm{hCG}$ suppresses proliferation of granulosa cells would be incorrect; hCG must have stimulated granulosa cell proliferation.

However, the third possible mechanism that could explain an increase in the proportion of $\mathrm{S}+\mathrm{G} 2+\mathrm{M}$ phase cells would result in an overall decrease in the rate of cell proliferation: the duration of $\mathrm{S}$ and $\mathrm{G} 2$ phases may have increased, and therefore the overall proportion of the total cell cycle time occupied by S and G2 phases would have increased as well. This might reflect an overall lengthening of the total cell cycle time, resulting in a reduced birth rate of new granulosa cells. If the observed phase shifts occurred by this third mechanism, our results conform to our original hypothesis, that $\mathrm{LH} / \mathrm{hCG}$ suppresses proliferation of granulosa cells.

Studies using other techniques suggest that cell proliferation slows down and eventually ceases in follicles undergoing atresia (Byskov, 1974; Hirshfield, 1984). Many of the follicles in this study must have been atretic. Therefore, we expected our flow cytometric data to include some follicles with very few 'cycling' cells. One follicle from an untreated animal contained only $2 \cdot 5 \%$ 'cycling' cells. However, all other follicles of untreated rats had more than $20 \%$ 'cycling' cells.

The static nature of flow cytometric analysis could be invoked to explain these results. Flow cytometry measures only the DNA content of cells and therefore does not reflect active progression of cells through the cell cycle. It is possible that, at the onset of atresia, cell cycle progression ceases. The DNA content of each granulosa cell remains fixed until cellular dissolution occurs. For this reason, we may have been unable to distinguish between atretic and healthy follicles on the basis of the phase fraction distribution alone.

Our inability to use flow cytometry to discriminate between healthy and atretic follicles of the rat contrasts with observations in human follicles. Westergaard et al. (1982) concluded that in humans "flow cytometric DNA measurements provide a reliable and rapid method to distinguish between healthy and atretic ovarian follicles". They found that $85 \%$ of follicles having S-phase fractions of $>16 \%$ were judged healthy by other criteria whereas $95 \%$ of follicles with S-phase fractions of $<16 \%$ were judged atretic by other criteria. However, nearly all of the follicles we studied had S-phase fractions of less than $16 \%$. Many of these follicles could not have been atretic.

This disparity in results may be due to the nature of the cell sample used. Many human samples were collected during aspiration of follicles for in-vitro fertilization procedures. Most of the cells in these aspirated samples are likely to come from the cumulus region; much of the follicle wall must be left intact to ensure adequate luteal function for the ensuing pregnancy. In contrast, our samples were probably from the entire granulosa layer, with a large representation of cells from the mural region of the follicle. Cumulus cells represent only $6-8 \%$ of the total granulosa area of antral follicles in the rat (A. N. Hirshfield, unpublished). 
The primary objective of this study was to assess the usefulness of flow cytometry for studies of follicle kinetics in rats. Flow cytometry has proved to be a powerful tool for many cell kinetic problems. It is most effective when applied to problems involving large homogeneous populations of easily dispersed cells, such as lymphocytes (Anastasi et al., 1987; Forsgren et al., 1987; Fidelus et al., 1987), cultured cell lines (Schliermann et al., 1987; Hoy et al., 1987), or ascites cells from tumours (Lewin et al., 1987). Many of these tissues permit multiple sampling and synchronization of cells; these procedures greatly increase the information content of flow cytometric data.

Granulosa cells are a heterogeneous population; each follicle contains a group of cells which differ in their maturational characteristics and viability from the cells in the next follicle. Therefore, possible questions we would like to address concerning the differential responses of individual follicles to hormonal stimuli or the regulation of early follicular growth cannot be investigated by pooling granulosa cells from follicles of different stages of development.

A single large antral follicle yielded barely enough granulosa cells to perform a valid flow cytometry analysis. Considerable numbers of small or medium sized follicles would be required to obtain sufficient cells for a single flow cytometry estimation. The difficulty of isolating small follicles for this purpose would be substantial. In addition, flow cytometry did not permit us to distinguish healthy versus atretic follicles. This information is essential for interpreting data concerning follicular development.

We therefore conclude that the variability between individual follicles, and the small number of cells that can be collected from young follicles or after certain treatments, limit the use of flow cytometry to the study of mature follicles in the rat. These limitations do not allow the investigator to address some of the pressing problems in follicular growth and atresia. However, flow cytometry remains a quick, inexpensive and powerful tool to evaluate the cell cycle in the rat, provided that it is applied to problems which conform to these limitations of the technique.

We thank Michael Varello and Jannitt Simons for technical assistance.

\section{References}

Anastasi, J., Bauer, K.D. \& Variakojis, D. (1987) DNA aneuploidy in Hodgkin's disease. A multiparameter flow-cytometric analysis with cytologic correlation. Am. J. Pathol. 128, 573-582.

Bartlett, M.S. (1947) The use of transformations. Biometrics 3, 39-52.

Ben-Rafael, Z., Varello, M.A., Meloni, F., Fateh, M., Mastroiani, L. \& Flickinger, G.L. (1987) Flow cytometric analysis of DNA in human granulosa cells from in vitro fertilization cycles: relationships to oocyte maturity and fertilizability and to follicular fluid steroids. J. clin. Endocr. metab. 65, 602-605.

Bennett, H.S., Wyrick, A.D., Lee, S.W. \& McNeil, J.H. (1976) Science and art in preparing tissues embedded in plastic for light microscopy with special reference to glycol methacrylate glass knives and simple stains. Stain Technol. 51, 71-97.

Byskov, A.G.S. (1974) Cell kinetic studies of follicular atresia in the mouse ovary. J. Reprod. Fert. 37, $277-285$.

Cheng, H. \& Bjerknes, M. (1983) Cell production in mouse intestinal epithelium measured by stathmokinetic flow cytometry and Coulter particle counting. Anat. Rec. 207, 427-434.

Eshkol, A. \& Pariente, C. (1984) Regulation of granulosa cell functions by cyclic AMP and cyclic GMP. In
Hormone Receptors in Growth and Reproduction, pp. 141-148. Eds B. B. Saxena, K. J. Catt, L. Birnbaumer \& L. Martini. Raven Press, New York.

Fidelus, R.K., Ginouves, P., Lawrence, D. \& Tsan, M.F. (1987) Modulation of intracellular glutathione concentrations alters lymphocyte activation and proliferation. Expl Cell Res. 170, 269-275.

Forsgren, A., Schlossman, S.F. \& Tedder, T.F. (1987) 4-Quinolone drugs affect cell cycle progression and function of human lymphocytes in vitro. Antimicrob. Agents Chemother. 31, 768-773.

Gurr, E. (1956) A Practical Manual of Medical and Biological Staining Techniques. Leonard Hill Books Ltd, London.

Hage, A.J., Groen-Klevant, A.G. \& Welschen, R. (1978) Follicle growth in the immature rat ovary. Acta endocr., Copenh. 88, 375-382.

Hirshfield, A.N. (1984) Continuous $\left[{ }^{3} \mathrm{H}\right]$ thymidine infusion: a method for the study of follicular dynamics. Biol. Reprod. 30, 485-491.

Hirshfield, A.N. (1985) Comparison of granulosa cell proliferation in small follicles of hypophysectomized, prepubertal and mature rats. Biol. Reprod. 32, 979-987.

Hirshfield, A.N. (1986) Patterns of $\left[{ }^{3} \mathrm{H}\right]$ thymidine incorporation differ in immature rats and mature, cycling rats. Biol. Reprod. 34, 229-235. 
Hirshfield, A.N. \& Schmidt, W.A. (1987) Kinetic aspects of follicular development in the rat. In Regulation of Ovarian and Testicular Function, pp. 211-236. Eds V. B. Mahesh, D. S. Dhindsa, E. Anderson \& S. P. Kalra. Plenum Press, New York.

Hoy, C.A., Rice, G.C., Kovacs, M. \& Schimke, R.T. (1987) Over-replication of DNA in S phase Chinese hamster ovary cells after DNA synthesis inhibition. J. biol. Chem. 262, 11927-11934.

Lewin, F., Skog, S., Tribukait, B. \& Ringborg, U. (1987) Effect of 5-fluorouracil on the cell growth and cell cycle kinetics of a mouse ascites tumor growing in vivo. Acta oncol. 26, 125-131.

Luna, L.G. (1968) Manual of Histological Staining Methods of the Armed Forces Institute of Pathology, 3rd edn. McGraw-Hill, New York.

Pedersen, T. (1969) Follicle growth in the immature mouse ovary. Acta endocr., Copenh. 62, 117-132.

Pedersen, T. (1970) Follicle kinetics in the ovary of the cyclic mouse. Acta endocr., Copenh. 64, 304-323.

Peluso, J.J. \& Steger, R.W. (1978) Role of FSH in regulating granulosa cell division and follicular atresia in rats. J. Reprod. Fert. 54, 275-278.

Peters, H. \& Levy, E. (1966) Cell dynamics of the ovarian cycle. J. Reprod. Fert. 11, 227-236.

Rao, M.C., Midgley, A.R. \& Richards, J.S. (1978) Hormonal regulation of ovarian cellular proliferation. Cell 14, 71-78.

Roy, S.K. \& Greenwald, G.S. (1986) Quantitative analysis of in-vitro incorporation of $\left[{ }^{3} \mathrm{H}\right]$ thymidine into hamster follicles during the oestrous cycle. J. Reprod. Fert. 77, 143-152.
Rubin, N.H., Hokanson, J.A. \& Bogdon, G. (1983) Circadian rhythms in phases of the cell cycle in the hamster as demonstrated by flow cytometry. Cell Tiss. Kinet 16, 115-123.

Schliermann, M., Beckers, C. \& Miltenburger, H.G. (1987) Cell cycle analysis by flow cytometry in an antibody secreting cell line. Dev. Biol. Stand. 66, $101-109$.

Tamura, H. \& Greenwald, G.S. (1987) Angiogenesis and its hormonal control in the corpus luteum of the pregnant rat. Biol. Reprod. 36, 1149-1154.

Tsou, K.C., Hong, D.H., Varello, M., Giuntoli, R., Wheeler, J.E., Atkinson, B.F., Mangan, C. \& Mikuta, J. (1984) Flow cytometric DNA analysis as a diagnostic aid for cervical condyloma and cancer. Cancer 54, 1778-1787.

Van Dilla, M.A., Dean, P.N., Laerum, O.D. \& Melamed, M.R. (Eds) (1985) Flow Cytometry: Instrumentation and Data Analysis. Academic Press, London.

Westergaard, L. (1985) Follicular atresia in relation to oocyte morphology in non-pregnant and pregnant women. J. Reprod. Fert. 74, 113-118.

Westergaard, L., McNatty, K.P., Christiansen, I., Larsen, J.K. \& Byskov, A.G. (1982) Flow cytometric DNA analysis of granulosa cells aspirated from human ovarian follicles. A new method to distinguish healthy and atretic ovarian follicles. J. clin. Endocr. Metab. 55, 693-698.

Winer, B.J. (1971) Statistical Principles in Experimental Design, Edition 2. McGraw-Hill, New York.

Received 20 January 1988 